\title{
WISATA VIRTUAL KAMPUNG KREATIF CIBUNUT FINEST
}

\author{
Mutia Tri Satya*, Ayi Tejaningrum, Hanifah \\ STIE Ekuitas Bandung \\ *mutia.satya@gmail.com
}

\begin{abstract}
Due to the Covid-19 pandemic, the tourism sector in Bandung has declined. Although at this time several tourist destinations in Indonesia have been opened by implementing various health protocols, such as LargeScale Social Restrictions (PSBB). and crafts. Cibunut Tourism Village has a unique concept, Cibunut Tourism Village applies the concept of "zero waste" and selfie village. Tourists can feel a different atmosphere from other villages. However, all of these activities have been suspended due to the COVID-19 pandemic. The impact on the decline in tourists visiting Cibunut Village, so that it greatly affects the economy of the Cibunut Village community as well. This program is run using a variety of hardware and software for video creation and virtual meeting procurement. The application used to conduct virtual meetings as a tool in virtual tours is the zoom application. The results of the activities that have been held show that with the webinar and Virtual Tours, it is expected that 50\% and even more than that the tourism industry will bounce back, especially in Cibunut Tourism Village. Videos of tourist attractions, local culinary and local products that are displayed and packaged in an attractive way. Can make every participant who attends this webinar as if they were in that place.
\end{abstract}

Keywords: covid-19, cibunut tourism village, virtual tour

\begin{abstract}
Abstrak
Akibat pandemic Covid-19, sektor pariwisata di Bandung menurun. Meskipun pada saat ini beberapa destinasi wisata di Indonesia telah dibuka dengan menerapkan berbagai protokol kesehatan, misalnya Pembatasan Sosial Berskala Besar (PSBB).Kondisi ini sangat mempengaruhi perokonomian masyarakat termasuk masyarakat Kampung Wisata Cibunut, masyarakat yang mata pencahariannya di tempat wisata seperti yang berjualan makanan daerah dan kerajinan. Kampung Wisata Cibunut memiliki konsep yang unik, Kampung Wisata Cibunut menerapkan konsep "zero waste" dan kampung selfie. Wisatawan dapat merasakan suasana yang berbeda dari kampung-kampung yang lainnya. Namun kegiatan itu semua sempat terhenti karena adanya pandemic COVID-19. Berimbas pada penurunan wisawatan yang berkunjung ke Kampung Cibunut, sehingga sangat mempengaruhi perekonomian masyarakat Kampung Cibunut juga. Program ini dijalankan dengan menggunakan berbagai perangkat lunak dank eras untuk pembuatan video dan pengadaan virtual meeting. Aplikasi yang digunakan untuk melakukan virtual meeting sebagai alat dalam tour virtual adalah aplikasi zoom. Hasil dari kegiatan yang telah digelar menunjukkan bahwa dengan adanya kegiatan webinar serta Wisata Virtual ini diharapkan $50 \%$ bahkan lebih dari itu industri pariwisata akan bangkit kembali terutama di Kampung Wisata Cibunut. Video objek wisata, kuliner lokal dan produkproduk lokal yang ditampilkan dan dikemas dengan menarik. Bisa membuat setiap peserta yang menghadiri webinar ini seolah-olah berada di tempat tersebut.
\end{abstract}

Kata Kunci: covid-19, kampung wisata cibunut, wisata virtual

Submitted: 2021-08-09

Revised: 2021-10-11

Accepted: 2021-10-26

\section{Pendahuluan}

Sejak mewabahnya coronavirus disease 19 atau yang lebih dikenal COVID-19 di seluruh dunia di pada tahun 2020, hampir seluruh negara melakukan antisipasi meluasnya penyebaran virus dengan salah satunya membatasi mobilisasi atau pergerakan penduduk baik yang akan masuk maupun keluar dari negaranya. Dengan meluasnya penyebaran COVID-19, pemerintah daerah semakin gencar melakukan sosialisasi kepada masyarakat agar tidak melakukan kegiatan di luar rumah, penyelenggaraan ibadah di rumah-rumah ibadah, serta perjalanan baik dalam maupun luar kota. Perluasan penyebaran virus COVID-19 berdampak pada semua sektor terutama perekonomian, hal serupa dialami pula oleh Kota Bandung. Sebagai ibu kota provinsi Jawa Barat, perekonomian kota Bandung ditunjang oleh beberapa aktifitas perekonomian salah satunya adalah pariwisata. 
Akibat pandemic Covid-19, sektor pariwisata di Bandung menurun. Berbagai upacara dilakukan pemerintah untuk kembali memperbaiki keadaan ekonomi, khususnya dalam sektor pariwisata. Meskipun pada saat ini beberapa destinasi wisata di Indonesia telah dibuka dengan menerapkan berbagai protokol kesehatan, misalnya Pembatasan Sosial Berskala Besar (PSBB), masih belum mampu meningkatkan minat kunjungan wisatawan, hal tersebut terjadi karena beberapa alasan diantaranya adalah kekhawatiran masyarakat akan tertular covid-19. Salah satu pariwisata di Bandung yang terkena imbas dari COVID-19 yaitu Kampung Wisata Cibunut. Data kunjungan wisatawan yang datang ke Kampung Wisata Cibunut sebanyak lebih dari 900 wisatawan yang diambil melalui rekapitulasi data kunjungan wisatawan untuk tahun 2019. Dari 900 wisatawan yang datang ke Kampung Wisata Cibunut seluruh pengunjung termasuk kategori wisatawan nusantara. Namun semenjak COVID-19 di awal tahun 2020 mewabah di Indonesia dan memasuki kawasan Bandung. Dengan diberlakukannya PSBB (Pembatasan Sosial Berskala Besar) di Bandung, di Bandung, wisatawan yang berkunjung ke Kampung Wisata Cibunut mengalami penurunan hingga $50 \%$.

Kondisi ini sangat mempengaruhi perokonomian masyarakat termasuk masyarakat Kampung Wisata Cibunut, masyarakat yang mata pencahariannya di tempat wisata seperti yang berjualan makanan daerah dan kerajinan. Dengan sepinya pengunjung maka penjualan dan kunjungan wisatawan sangat menurun. Selain itu terhentinya kegiatan kepariwisataan ini, dapat mengakibatkan kejenuhan masyarakat yang terpaksa berdiam diri di rumah masing-masing. Melihat fenomena ini, dibutuhkan alternatif cara berwisata pada saat pandemi. Salah satu konsep berwisata yang dapat dilakukan pada saat pandemi sekarang ini adalah wisata virtual. Konsep wisata virtual ini merupakan salah satu bentuk berwisata dimana wisatawan dapat menikmati objek wisata tanpa harus mengunjungi objek wisata secara langsung. Selain objek wisata, wisatawan bisa mengetahui apa saja kegiatan-kegiatan yang ada di dalam tempat wisata. Seperti yang berjualan kerajinan, pameran seni daerah dan makanan daerah.

Tujuan wisata merupakan kunci untuk meningkatkan produktivitas pariwisata (Liu dan Wu, 2019). Penelitian terdahulu yang dilaksanakan oleh Blake, Sinclair, dan Soriav (2006) membandingkan efek dari produktivitas berbagai sektor pariwisata pada pembangunan ekonomi. Liu, Song, dan Blake (2018) menerapkan teori pertumbuhan ekonomi eksogen, yang mengasumsikan bahwa produktifitas eksogen dan kembalinya kapitalis berkurang, untuk mensimulasikan mekanisme transmisi dari sebuah productivity shock pada pariwisata eksogen terhadap pertumbuhan ekonomi di Mauritius dengan menggunakan model keseimbangan stokastik umum (DSGE) yang dinamis. Di samping itu, pemerintah Indonesia berharap sektor pariwisata dapat menjadi mesin penggerak ekonomi sehingga mampu memberikan sumbangsih untuk mensejahterakan masyarakat (Abdillah, 2017). Oleh karena itu selama pandemic COVID-19 mewabah dan terhentinya kegiatan wisata. Terutama di Kampung Wisata Cibunut Bandung, agar kegiatan wisata bisa berjalan lagi walaupun masih dalam pandemic COVID-19 akan diselenggarakan wisata virtual dan webinar seputar kawasan Kampung Wisata Cibunut. Dengan ada wisata virtual ini dapat membantu membangkitkan Kembali perekonomian masyarakat Kampung Wisata Cibunut. Kegiatan ini juga meminimalisir rasa kejenuhan wisatawan yang senang berwisata, dengan berwisata dirumah saja tanpa harus mendatangi langsung yang dipastikan aman dan terjauh dari tertularnya COVID-19. Selain wisata virtual ada juga webinar seputar Kampung Wisata Cibunut, dengan partisipan wisatawan dan para pelajar. Dengan tujuan yang sama yaitu memperkenalkan seputar kegiatan-kegiatan dan kreatifitas Kampung Wisata Cibunut.

Objek wisata yang menjadi objek pengabdian ini adalah Kampung Kreatif Cibunut Finest, Cibunut ini yang digagas oleh masyarakat, lokasinya di jalan sunda di kota Bandung. Dalam dua tahun kampung ini sudah stabil, dari segi lingkungannya. Padahal sebelumnya kampung itu merupakan daerah beling yang banyak copetnya, narkoba, tapi dari segi lingkungan sudah berkurang. Bedanya dengan Creative Cities dago pojok dalam hal pendiriannya, pendirian 
kampung ini melibatkan komunitas-komunitas dari kelompok umur dari TK, SMP, Pemuda, orangtua semua berpartisipasi untuk bisa mengembangkan kampung wisata kreatif ini. Kemudian yang menjadi keunggulan kampung ini adalah muralnya tematik dimana setiap RT itu ada muralnya. Juga dikarenakan pengaruh media social, Ketua mural sedunia datang ke kampung Cibunut. Keunggulan yang lainnya adalah kampung ini menjadi percontohan di indonesia untuk kampung daur ulang sampah. jadi disitu sampah itu tidak ada yang dibuang semua sampah itu di daur ulang. Kampung wisata cibunut Sekarang secara ekonomi sudah berdampak dari pengolahan limbah sampah, dari tujuan wisatanya sudah sangat di minati membuat ekonomi masyarakatnya meningkat, ini menunjukan ketika suatu ide digagas oleh masyarakat itu akan cepat berkembang. Ketika suatu kegiatan dibentuk oleh masyarakat akan terlihat berbeda dengan kegiatan yang dibentuk oleh pemerintah, kegiatan yang dibentuk masyarakat akan terlihat jauh lebih keren bahkan melebihi ekspektasi karena masyarakat melakukan kegiatan tersebut dengan bahu membahu. Kampung Cibunut awal mulanya adalah menjadi Kawasan Bebas Sampah (KBS). Di dalam KBS itu ada Kelompok Swadaya Masyarakat (KSM). Nama KSM nya adalah Oh- Darling itu merupakan singkatan dari Orang Hebat Sadar Lingkungan. KSM itu mitra sejajar RW, dan diharapkan KSM ini akan selalu ada. Pada umumnya jika ada pergantian ketua RW baru lingkungan jadi kurang diperhatikan, dan KSM jadi kurang berjalan. Sementara di Kampung Cibunut KSM harus tetap aktif meskipun adanya pergantian RW, dan anggota KSM terdiri dari orang-orang yang benar-benar peduli dengan lingkungan.

Produk kerajinan yang ada bermula dari adanya mahasiswa S2 design produk ITB yang melakukan TA di Kampung Cibunut. Mahasiswa tersebut mengedukasi warga Cibunut untuk pembuatan produk kerajinan. Mahasiswa tersebut yang membuat desain produk serta menyediakan bahannya, masyarakat hanya tinggal mengikuti pelatihan dan merajut bahan yang ada menjadi barang setengah jadi. Barang setengah jadi yang sudah dibuat dibawa kembali oleh mahasiswa tersebut untuk tahap finishing dan menjualnya. Masyarakat tidak tahu kemana produk itu dijual, mereka hanya di bayar untuk merajut bahan yang dibawa, dan masyarakat juga dibayar atas hasil rajutannya. Tapi seiring berjalannya waktu banyak yang berkunjung ke Kampung Cibunut ini dan melihat adanya produk kerajinan dan melakukan transaksi secara langsung. Produk juga sering ditampilkan di berbagai acara pameran seperti di Balai Kota, dari pameran tersebut mulai timbul banyak permintaan, bahkan dari luar kota. Sebelum adanya mahasiswa tersebut, kerajinan yang ada disini masih sangat sederhana dan belum memiliki konsep desain seperti yang dibuat. Saat ini kerajinan yang ada terbuat dari limbah an-organik yang diubah menjadi berbagai produk seperti tas, tempat tissue, dan sebagainya. Harga yang dibandrol untuk kerajian tersebut sekitar Rp200.000 hingga Rp450.000. Lingkup pemasaran produk sudah sampai keluar kota, seperti Kota Medan, Surabaya, dan Jakarta.

Selain mengolah sampah menjadi kerajinan, masyarakat Cibunut juga pengolahan sampah organik dijadikan biodigester, mengubah sampah menjadi gas lalu terdapat bata terawang untuk pembuatan pupuk organik. Susunan pupuk organik terdiri dari daun kering, serbuk gergaji, lalu sampah organik, lapisannya terus menerus diulang. Untuk mengurangi bau sampah organik Kampung Cibunut menggunakan cairan MOL (Mikro Organisme Lokal) yang dibuat sendiri. MOL dibuat dari air cucian beras yang pertama, lalu air kelapa, takarannya satu banding satu, bila akan membuat 5 liter air beras berarti air kelapanya juga harus 5 liter, lalu memasukan gula merah satu gandul, itu untuk mengaktifkan bakteri. Lalu aroma, aroma bisa dari buah-buahan yang busuk saja, tergantung selera. Nanas misalnya atau pisang, mangga, masukkan ke dalam campuran, disimpan di fermentasi selama 2 minggu, ditutup rapat agar tidak terkena udara, jika terjadi kebocoran maka akan terkontaminasi dan gagal. setelah dua minggu cairan di saring, lalu dari cairan yang disaring sebanyak 5 liter itu ditambah 1 liter air biasa.

Seiring dengan berhasilnya Program Kawasan Bebas Sampah, mulailah disini ada ide dari seluruh warga sekitar Cibunut untuk menjadikannya Creative Cities. Kerjasama masyarakat dengan 
pihak swasta meliputi pemberian barang berupa cat sebagai bahan dasar untuk membuat desain mural di Kampung Cibunut. Sedangkan kerjasama yang dilakukan dengan komunitas lokal yaitu dengan komunitas mural bandung dan beberapa komuntas pegiat lingkungan seperti Earth Hour Bandung. Selanjutnya dimulai dengan membuat konsep mural yang menarik dan tematik. Mural tematik inilah yang menjadikan Cibunut berbeda dengan kampung kreatif Dago Pojok, dimana kawasan ini mempunya ciri khas dan daya tarik sendiri dengan konsep mural yang berbeda. Seperti untuk pembagian zona warna dilakukan sesuai dengan wilayah RT yang ada, terdapat 10 RT yaitu RT 01 warna hijau muda, RT 02 warna biru persib, RT 03 pink, RT 04 kuning, RT 05 merah, RT 06 hijau mint, RT 07 biru muda, RT 08 ungu, RT 09 orange

Muralnya itu bertema ada lima zona. Zona pertama di RT $1 \& 2$ tentang kebudayaan. Zona ke dua bertema kuliner khas bandung dimana terdapat gambar mie kocok, seblak, gehu, ada mural yang berkonsep masyarakat yang sedang makan bersama menandakan kebersamaan warga Cibunut menjadi prioritas utama. Zona ke 3 berwarna kuning tentang pendidikan. Zona ke 4 tentang lingkungan, konsepnya pusat edukasi tempat bermain yang menampilkan permainan tradisional seperti congklak dan berbagai permainan zaman dulu. Terakhir zona ke lima itu tentang perdamaian, yang berwarna biru muda terdapat gambar api peperangan.

Karakteristik kawasan nilai budaya yang berwujud fisik ialah setiap lingkungan RT Kampung Cibunut memiliki tema warna dan fungsinya masing-masing. Nilai budaya yang berwujud non-fisik diantaranya bentuk toleransi dan kreativitas Kampung Cibunut lebih kepada mempererat hubungan kekerabatan yang telah terjalin di Kampung Cibunut seperti saling menghargai antar sesama umat beragama, agenda rutin seperti acara makan-makan, dsb. Masyarakat juga ikut berpartisipasi aktif dalam setiap kegiatan yang dilaksanakan. Dalam setahun saja ada lebih dari 5 kegiatan yang rutin dilaksanakan setiap tahunnya, diantaranya culinary night untuk menyambut hari kemerdekaan, agustusan pada hari kemerdekaan, oktoberan untuk menyambut hari sumpah pemuda, rekreasi ke Pantai Pangandaran dan malam puncak yang dijadikan ajang reuni dan silaturahmi bagi masyarakat Kampung Cibunut yang sudah berpindah tempat.

Kampung Wisata Cibunut memiliki konsep yang unik, Kampung Wisata Cibunut menerapkan konsep "zero waste" dan kampung selfie. Wisatawan dapat merasakan suasana yang berbeda dari kampung-kampung yang lainnya. Selain dapat merasakan suasana yang berbeda, wisatawan juga dapat langsung melihat pengelolaan sampah organik menjadi biogester. Aktivitas di Kampung Wisata Cibunut, paling banyak diminati dan dilakukan oleh wisatawan yang datang ke Kampung Wisata Cibunut pada hari-hari di akhir pekan maupun hari libur nasional bersama teman, dan keluarga, antara lain wisatawan datang umumnya untuk mengetahui cara pengolahan limbah organik menjadi biogester yang hasilnya dapat dimanfaatkan oleh masyarakat sekitar untuk kebutuhan sehari-hari.

Wisatawan tidak hanya melihat cara mengolah sampah tetapi dapat mengikuti proses pembuatan dari mulai memilah sampah hingga siap digunakan. Wisatawan pun dapat selfie di tembok-tembok mural berbeda tema setiap wilayah yang membuat ciri khas berbeda antara Kampung Wisata Cibunut dengan kampung lainnya. Hal ini menunjukan bahwa kemenarikan atraksi dengan dimensi kemenarikan aktivitas wisata di Kampung Wisata Cibunut cukup menarik perhatian wisatawan dengan pengetahuan yang didapat menjadi daya tarik tersendiri bagi wisatawan untuk datang ke Kampung Wisata Cibunut.

Kampung Wisata Cibunut telah dilengkapi dengan beberapa fasilitas wisata, namun hingga saat ini masih dalam jumlah dan kondisi yang terbatas. Fasilitas tersebut antara lain:

1) Lahan Parkir

Kampung Wisata Cibunut memiliki satu pintu masuk melalui gang Cibunut. Lokasi Kampung Wisata Cibunut ini memiliki 2 lahan parkir. Lahan parkir pertama tidak jauh dari jalan raya sehingga pengunjung yang membawa kendaraan pribadi roda empat disediakan tempat parkir di 
lahan pertokoan. Sedangkan satu lahan parkir disediakan untuk pengunjung yang membawa kendaraan roda dua di lapangan RT 09. Keamanannya pun terjaga karena terdapat pos keamanan berikut dengan petugasnya.

2) Toilet

Toilet merupakan fasilitas yang harus terdapat pada setiap daya tarik wisata. Kampung Wisata Cibunut mempunyai toilet yang tersedia di beberapa rumah masyarakat.

3) Sarana Informasi Wisata

Sarana informasi merupakan fasilitas yang harus terdapat pada setiap daya tarik wisata. Kampung Wisata Cibunut memiliki sarana Informasi yang bertempat di balai RW 07. Petugas yang menjaga sarana informasi ini didominasi oleh karang taruna, yang selalu ada dengan cara bergantian waktu (shift).

4) Shelter

Shelter yang disediakan oleh Kampung Wisata Cibunut relatif kecil karena hanya dapat menampung sekitar 50 pengunjung yang ingin melihat pengolahan Biogas.

5) Tempat Ibadah

Kampung Wisata Cibunut menyediakan 2 (dua) masjid yang tersebar di beberapa tempat, seperti masjid yang berada di dekat shelter dan di dekat pemukiman masyarakat.

Namun kegiatan itu semua sempat terhenti karena adanya pandemic COVID-19. Berimbas pada penurunan wisawatan yang berkunjung ke Kampung Cibunut, sehingga sangat mempengaruhi perekonomian masyarakat Kampung Cibunut juga. Bila di hari-hari normal sebelum COVID-19 Kampung Cibunut selalu ada wisawatan yang berkunjung membeli kerajinan dan kuliner lokal kampung cibunut. Namun sekarang tidak ada yang berkunjung ke Kampung Wisata Cibunut. Maka dari itu solusi untuk membangkitkan wisatawan dengan menggunakan cara wisata virtual.

\section{Metode}

Program ini dijalankan dengan menggunakan berbagai perangkat lunak dank eras untuk pembuatan video dan pengadaan virtual meeting. Aplikasi yang digunakan untuk melakukan virtual meeting sebagai alat dalam tour virtual adalah aplikasi zoom. Untuk membuat tur virtual, setiap operator wajib menguasai teknologi informasi. Karena hampir $90 \%$ aktivitas tur ini memanfaatkan teknologi digital agar peserta merasa sedang benar-benar berada dilokasi tujuan wisata. Mulai dari pemanfaatan aplikasi kamera 3600 untuk menghasilkan gambar statis dari suatu obyek yang mampu digerakkan ke segala arah. Hal tersebut akan membuat peserta seolah-olah seperti sedang berada di lokasi tersebut. Ditambah pula dengan dokumentasi video dari lokasi yang dituju agar nuansa berwisata semakin terasa. Selain itu para operator juga memanfaatkan aplikasi peta digital Google Maps dan Google Street View supaya makin menghidupkan suasana tur. Agar mirip dengan sebuah perjalanan wisata, setiap operator tak lupa melengkapinya dengan pemandu wisata (tour guide) professional yang akan menjelaskan segala hal terkait lokasi wisata yang dituju. Sistematika pelaksanaan tur virtual yang akan dijalankan secara ringkas dapat dijabarkan sebagai berikut:

1. Peserta melakukan pendaftaran

2. Pada waktu yang ditentukan, para peserta wajib standby di akun Zoom masing-masing untuk kemudian diajak berselancar bersama-sama mengunjungi setiap sisi dari Kampung Cibunut.

3. Peserta akan diajak merasakan bagaimana rasanya melakukan berbagai kegiatan recycle dengan di pandu oleh pihak pengurus Kampung Cibunut.

4. Menjelajah destinasi wisata dengan dipandu oleh pengurus Kampung Cibunut dengan menampilkan berbagai foto lingkungan dan kegiatan yang ada di Kampung Cibunut.

Produk teknologi yang akan dibuat adalah wisata virtual dan video objek wisata. objek wisata ini (Kampung Wisata Cibunut) adalah program yang sedang digalakakan dan menjadi konsentrasi pemerintah dalam membangkitkan industri pariwisata. 
Prosedur kerja untuk program ini adalah dari semua tim yang harus saling mendukung dan kompak selama kegiatan ini berlangsung. Karena kegiatan ini sangat melibatkan banyak pihak. Dimana kami membagi kegiatan ini sesuai dengan keahlian dan kompetensi dari masing-masing tim. Di awal bulan pertama kami akan melakukan survey ke objek wisata yang telah ditentukan, lalu mencari objek wisata yang sangat menarik untuk diangkat. Ada tim fotografi dan video, yang bertugas mengambil spot yang menarik. Kemudian ada tim script writer yang bertugas membuat narasi pada saat video atau gambar ditampilkan. Di bulan kedua kami akan melakukan promosi untuk kegiatan webinar ini, karena target yang dicapai adalah 1000 peserta. Webinar ini akan dilakukan 10 kali dan harus tepat sasaran dalam hal ini adalah masyarakat yang menyukai perjalanan. Promosi yang akan lakukan selain di media sosial masing-masing tim, juga di google ads, facebook ads, dan juga Instagram ads.

Partisipasi mitra sangat dibutuhkan sekali, kami sudah menyepakati pada saat pembuatan video dan fotografi itu dari pihak mitra. Mereka juga akan menyediakan guide/pemandu wisata yang akan melakukan survey ke objek wisata yang telah ditentukan.

\section{Hasil dan Pembahasan}

Tourism mempengaruhi economic growth (Liu dan Wu, 2019; Inchausti-Sintes, 2015; Santamaria dan Fillis, 2019), maka pengembangan tourism harus dilakukan agar dapat memberikan kontribusi terus menerus terhadap pertumbuhan ekonomi. Kegiatan wisata virtual sedang menjadi tren di kalangan penikmat wisata petualangan di saat pandemi corona seperti sekarang ini. Tak perlu harus repot memesan tiket transportasi dan akomodasi penginapan, para penikmat wisata petualangan cukup bermodalkan komputer atau laptop yang terhubung dengan internet serta mengunduh aplikasi Zoom.

Hadirnya wisata virtual dengan memanfaatkan kemajuan teknologi digital pada masa pandemic COVID-19 merupakan sebuah peluang baru bagi para pegiat dan operator wisata. Terlebih lagi dengan dibatasinya ruang gerak masyarakat untuk mencegah penyebaran virus corona, maka berwisata sambil tetap berada di rumah menghadirkan sebuah pengalaman baru.

Melalui media teknologi digital telah membawa masyarakat kepada rutinitas dan cara hidup yang baru dengan hadirnya wisata virtual. Kendati demikian, wisata virtual tidak dapat menggantikan pengalaman ketika berwisata langsung ke lokasi sesungguhnya. Platform wisata digital dapat melihat peluang tur wisata maya ini dengan membuka kegiatan pelatihan pramuwisata khusus untuk. Terlebih ketika industri pariwisata makin lesu dihantam pandemic COVID-19 akibat terbatasnya ruang gerak wisatawan untuk mengunjungi sebuah obyek wisata. Melalui wisata virtual ini wisatawan yang melihat di aplikasi Zoom akan mendapatkan gambaran suasana di lokasi wisata. Pengelola wisata dapat menyediakan foto destinasi sekitar.

Dengan adanya wisata virtual ini bisa menstimulusi para wisatawan kepada Kampung Wisata Cibunut. Di dukung dengan webinar wisata virtual yang memberi kesan dan pengalaman yang mendalam untuk para peserta yang mengikuti wisata virtual ini. Hal ini tentu didukung dari kekuatan teknologi yang menampilkan audio dan video yang menarik. Dengan kegiatan webinar ini $50 \%$ industry pariwisata akan bangkit Kembali terutama di Kampung Wisata Cibunut. Video objek wisata, kuliner lokal dan produk-produk lokal yang ditampilkan dan dikemas dengan menarik. Bisa membuat setiap peserta yang menghadiri webinar ini seolah-olah berada di tempat tersebut. $90 \%$ peserta yang hadir akan sangat menikmati sajian video yang di tayangkan.

Bangkitnya industri pariwisata dalam hal ini adalah Kampung Wisata Cibunut sebagai tempat wisata di Kota Bandung yang kreatif, ramah lingkungan dan kampung selfi karena banyak muralmural yang menarik dan kekinian. Melalui kegiatan wisata virtual yang akan kami lakukan dengan konsep dan program semenarik mungkin. Indikator untuk mencapai hal ini adalah teknologi yang digunakan sangat mendukung untuk pelaksanaan wisata virtual Kampung Wisata Cibunut. Dari mulai peralatan video, seperti handycam, kamera, penggunaan audio, aplikasi webinar dan juga 
peralatan lain yang mendukung pembuatan video dan webinar wisata virtual. Hasil video akan diunggah di channel youtube kami, web STIE Ekuitas, dan juga media sosial lainnya seperti Instagram, facebook dan tiktok.

Hasil dari kegiatan yang telah digelar menunjukkan bahwa dengan adanya kegiatan webinar serta Wisata Virtual ini diharapkan $50 \%$ bahkan lebih dari itu industri pariwisata akan bangkit kembali terutama di Kampung Wisata Cibunut. Video objek wisata, kuliner lokal dan produk-produk lokal yang ditampilkan dan dikemas dengan menarik. Bisa membuat setiap peserta yang menghadiri webinar ini seolah-olah berada di tempat tersebut.

Kegiatan Webinar yang berlangsung merupakan hasil akhir dalam Kegiatan Wisata Virtual. Kegiatan tersebut digelar pada 27 April 2020 dengan banyaknya peserta yang mengikuti kegiatan ini. Dalam kegiatan juga dihadiri oleh Bapak Edward Parlindungan., S.Sos., MT. yang merupakan Kepala Bidang Kepariwisataan, kami berterimakasih kepada beliau karena telah menyempatkan untuk berpartisipasi dalam mengisi acara, serta juga tak lupa kami ingin berterimakasih kepada Warga Cibunut dan beberapa pihak yang telah membantu dalam mensukseskan kegiatan pengabdian masyarakat ini.

Webinar berdurasikan satu jam 19 menit. Pengaturan serta pengisi acara dari kami sendiri, MC sekaligus pemandu acara yakni Mutia Tri Satya., S.Sos., Msi., MSM., CT. Moderator acara adalah Dr hanifah., SE., Msi., Ak., CA., QIA., CACP., CAPM., CAPF serta pengisi materi yaitu Dr. Ayi Tejaningrum., SE., MT. Pemaparan materi yang disampaikan yakni mengenai kegiatan pengabdian yang kami lakukan kepada masyarakat dengan studi kasus Cibunut. Dengan membuat wisata virtual agar kegiatan pariwisata daerah tetap berjalan meskipun adanya pembatasan sosial. Wisata virtual ini dilakukan dengan memanfaatkan kemajuan teknologi digital melalui media platform digital telah membawa masyarakat kepada rutinitas dan cara hidup yang baru. Platform wisata digital dapat melihat peluang tur wisata maya ini dengan membuka kegiatan pelatihan pramuwisata khusus. Terlebih ketika industri pariwisata menurun akibat terbatasnya ruang gerak wisatawan untuk mengunjungi sebuah obyek wisata. Melalui wisata virtual ini wisatawan yang melihat di aplikasi Zoom akan mendapatkan gambaran suasana di lokasi wisata. Pengelola wisata dapat menyediakan foto destinasi sekitar.

Dalam kegiatan Webinar ini dijelaskan juga bahwa dengan adanya wisata virtual menjadi solusi untuk penurunan bidang pariwisata, selain itu dapat mengajak para wisatawan untuk melihat serta berwisata Kampung Wisata Cibunut meskipun secara virtual. Pemaparan didukung dari kekuatan teknologi yang menampilkan audio dan video yang menarik. Kami menjelaskan secara rinci mengenai kunjungan kami dalam format video dibuat agar peserta dapat merasakan euforia berwissata seolah-olah berada di tempat tersebut. Saat pemaparan pun peserta memberikan respon positif selama penayangan video.

HASIL WISATA VIRTUAL SERTA SEMINAR

Berikut kami lampirkan hasil gambar dari wisata virtual seminar yang telah digelar.

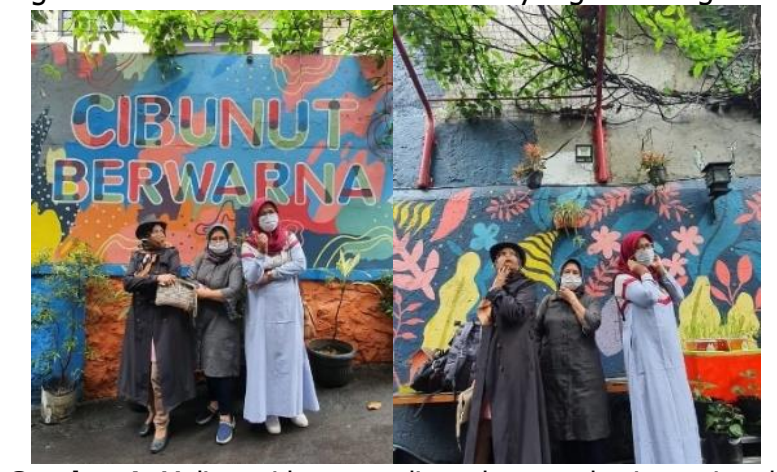

Gambar 1. Meliput video yang digunakan untuk wisata virtual. 
BERNAS:

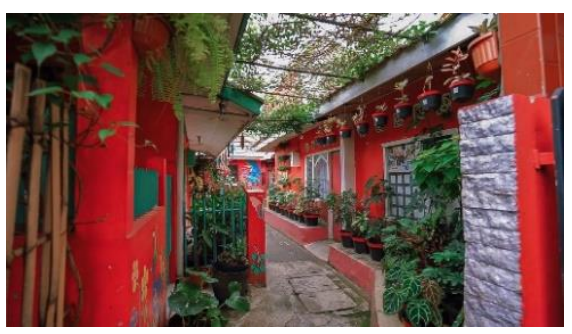

Gambar 2. Jalan Gang menuju Cibunut

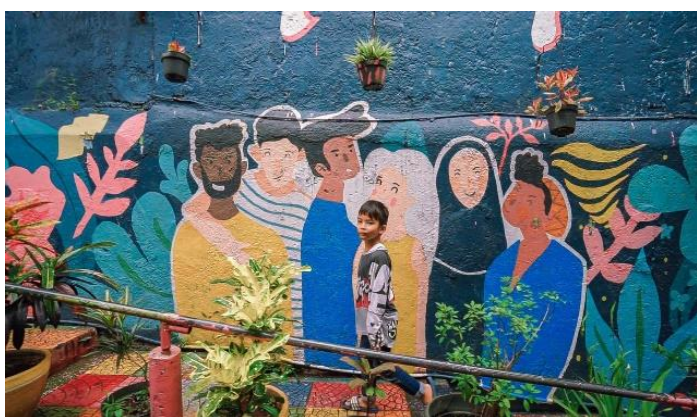

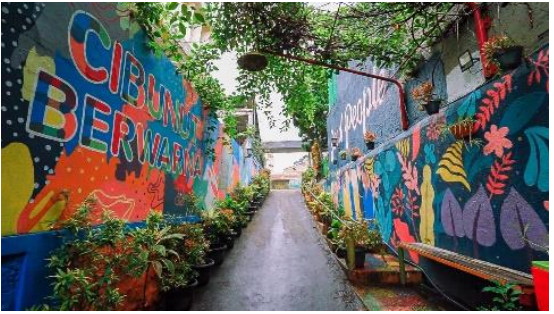

Gambar 3 Rumah Warga Cibunut

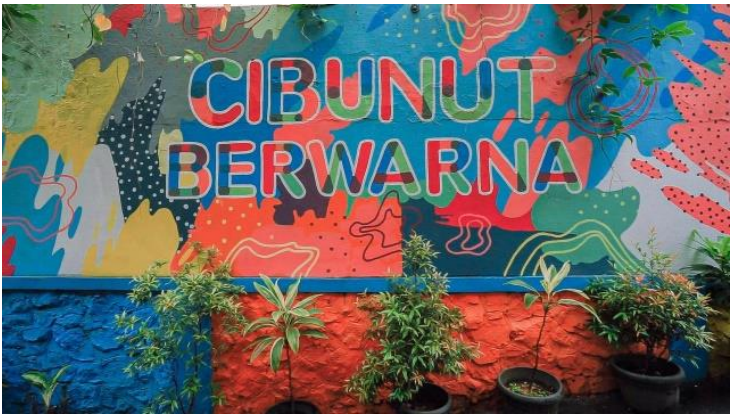

Gambar 4 lokasi Cibunut yang penuh dengan warna warni yang menggambarkan bahwa memiliki tagline "Cibunut Berwarna".

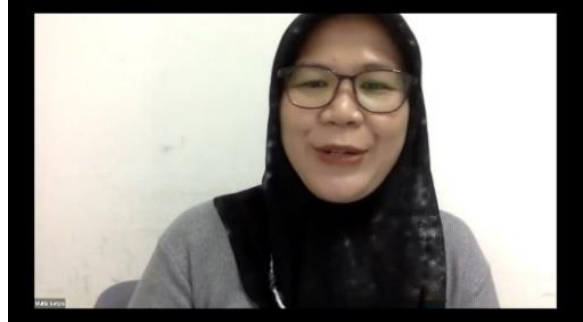

Gambar 5 MC membuka acara

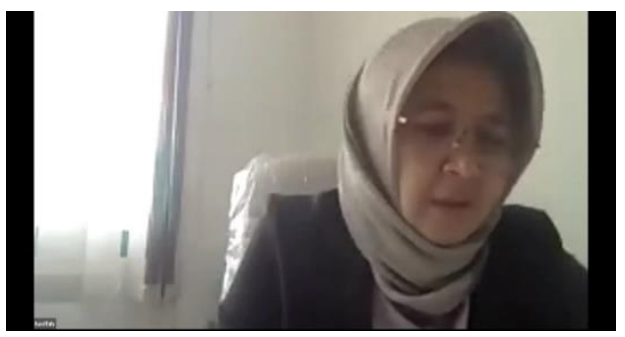

Gambar 7 Moderator membacakan Profil Narasumber

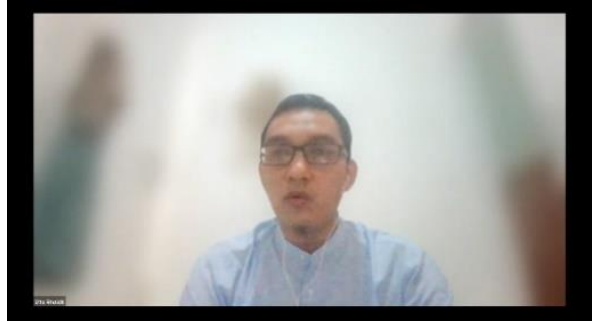

Gambar 6 Sambutan Ketua LPPM

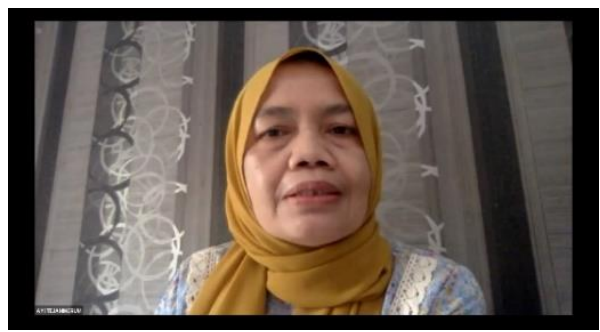

Gambar 8 Pemberi Materi

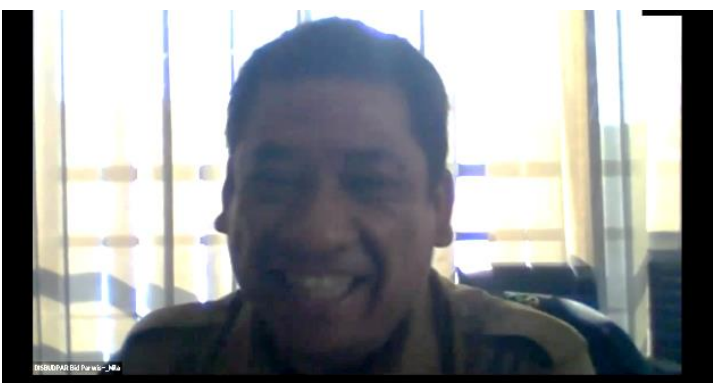

Gambar 9 Kepala Bidang Kepariwisataan Bapak Edward 

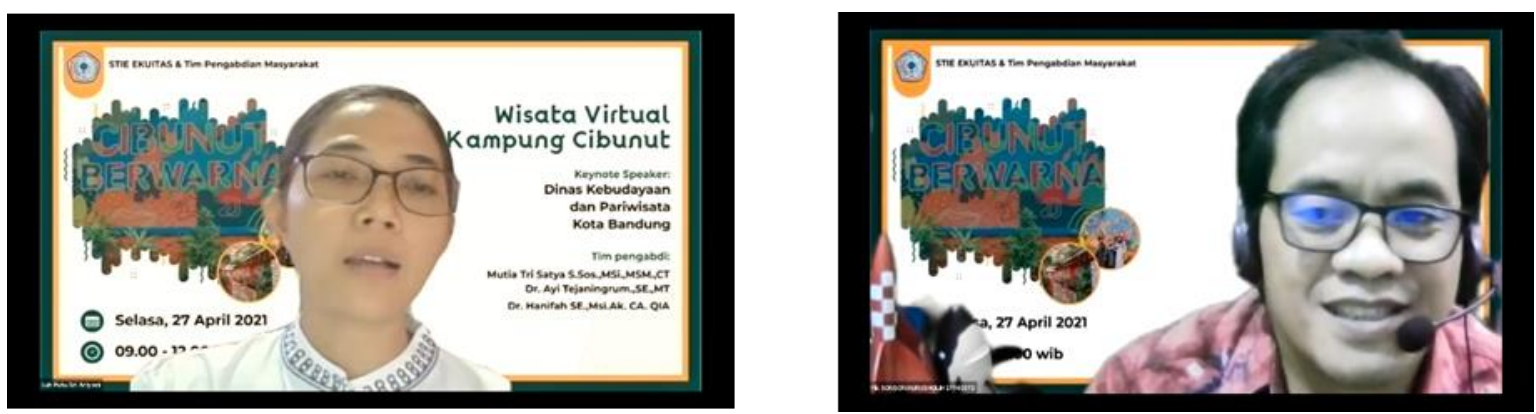

Gambar 13 Sesi Tanya jawab, Ibu Lulu yang berasal dari Bali

Gambar 14 Sesi Tanya Jawab, Bapak Sonson dari Universitas Telkom

\section{Kesimpulan}

Kesimpulan dari pengabdian ini adalah dengan upaya membantu meningkatkan wisata daerah yang kini sedang menurun akibat adanya Covid-19, maka kami berinisiatif untuk menggelar adanya Wisata Virtual sebagai bentuk pengabdian kami kepada masyarakat. Dengan adanya Wisata Virtual ini selain membantu pemerintah juga membantu warga Kampung Cibunut yang masyarakat yang mata pencahariannya di tempat wisata seperti yang berjualan makanan daerah dan kerajinan.

Objek wisata yang menjadi objek pengabdian ini adalah Kampung Kreatif Cibunut Finest, Cibunut ini yang digagas oleh masyarakat, lokasinya di jalan sunda di kota Bandung. Kampung Wisata Cibunut memiliki konsep yang unik, Kampung Wisata Cibunut menerapkan konsep "zero waste" dan kampung selfie. Wisatawan dapat merasakan suasana yang berbeda dari kampungkampung yang lainnya. Selain dapat merasakan suasana yang berbeda, wisatawan juga dapat langsung melihat pengelolaan sampah organik menjadi biogester. Program ini dijalankan dengan menggunakan berbagai perangkat lunak dank eras untuk pembuatan video dan pengadaan virtual meeting. Aplikasi yang digunakan untuk melakukan virtual meeting sebagai alat dalam tour virtual adalah aplikasi zoom. Produk teknologi yang akan dibuat adalah wisata virtual dan video objek wisata. objek wisata ini (Kampung Wisata Cibunut) adalah program yang sedang digalakakan dan menjadi konsentrasi pemerintah dalam membangkitkan industri pariwisata. Prosedur kerja untuk program ini adalah dari semua tim yang harus saling mendukung dan kompak selama kegiatan ini berlangsung. Partisipasi mitra sangat dibutuhkan sekali, kami sudah menyepakati pada saat pembuatan video dan fotografi itu dari pihak mitra. Mereka juga akan menyediakan guide/pemandu wisata yang akan melakukan survey ke objek wisata yang telah ditentukan.

Hasil dari kegiatan yang telah digelar menunjukkan bahwa dengan adanya kegiatan webinar serta Wisata Virtual ini diharapkan $50 \%$ bahkan lebih dari itu industri pariwisata akan bangkit kembali terutama di Kampung Wisata Cibunut. Video objek wisata, kuliner lokal dan produk-produk lokal yang ditampilkan dan dikemas dengan menarik. Bisa membuat setiap peserta yang menghadiri webinar ini seolah-olah berada di tempat tersebut.

Kegiatan Webinar yang berlangsung merupakan hasil akhir dalam Kegiatan Wisata Virtual. Kegiatan tersebut digelar pada 27 April 2020 dengan banyaknya peserta yang mengikuti kegiatan ini. Dalam kegiatan juga dihadiri oleh Bapak Edward Parlindungan., S.Sos., MT. yang merupakan Kepala Bidang Kepariwisataan, kami berterimakasih kepada beliau karena telah menyempatkan untuk berpartisipasi dalam mengisi acara, serta juga tak lupa kami ingin berterimakasih kepada Warga Cibunut dan beberapa pihak yang telah membantu dalam mensukseskan kegiatan pengabdian masyarakat ini. 
Webinar berdurasikan satu jam 19 menit. Pengaturan serta pengisi acara dari kami sendiri, MC sekaligus pemandu acara yakni Mutia Tri Satya., S.Sos., Msi., MSM., CT. Moderator acara adalah Dr hanifah., SE., Msi., Ak., CA., QIA., CACP., CAPM., CAPF serta pengisi materi yaitu Dr. Ayi Tejaningrum., SE., MT. Pemaparan materi yang disampaikan yakni mengenai kegiatan pengabdian yang kami lakukan kepada masyarakat dengan studi kasus Cibunut. Dengan membuat wisata virtual agar kegiatan pariwisata daerah tetap berjalan meskipun adanya pembatasan sosial. Wisata virtual ini dilakukan dengan memanfaatkan kemajuan teknologi digital melalui media platform digital telah membawa masyarakat kepada rutinitas dan cara hidup yang baru. Platform wisata digital dapat melihat peluang tur wisata maya ini dengan membuka kegiatan pelatihan pramuwisata khusus. Terlebih ketika industri pariwisata menurun akibat terbatasnya ruang gerak wisatawan untuk mengunjungi sebuah obyek wisata. Melalui wisata virtual ini wisatawan yang melihat di aplikasi Zoom akan mendapatkan gambaran suasana di lokasi wisata. Pengelola wisata dapat menyediakan foto destinasi sekitar.

\section{Daftar Pustaka}

Abdillah, D. (2017). Analisis Faktor Pendorong dan Penarik Motivasi Wisatawan Berkunjung ke Bali Utara. Jurnal Kepariwisataan Indonesia: Jurnal Penelitian Dan Pengembangan Kepariwisataan Indonesia, 12(1), 81-110.

Blake, Adam., Sinclair, M Thea., dan Soria, Juan Antonio Campos. (2006). Tourism productivity: Evidence from the United Kingdom. Annals of Tourism Research, DOI: doi.org/10.1016/j.annals.2006.06.001

Law, R., Sun, S., Fong, D., Fong, L., dan Fu, H. (2016). A systematic review of China's outbound tourism research. International Journal of Contemporary Hospitality. DOI: 10.1108/IJCHM06-2015-0323

Liu, Anyu., Song, Haiyan., dan Blake, Adam. (2018). Modelling productivity shocks and economic growth using the Bayesian dynamic stochastic general equilibrium approach, International Journal of Contemporary Hospitality Management, DOI: 10.1108/IJCHM-10 2017-0686

Liu, Anyu., dan Wu, Doris Chenghuang. (2019). Tourism productivity and economic growth, Annals of Tourism Research, DOI: 10.1016/j.annals.2019.04.005

Arofah, L. dan Suheri, T. (2018). Kajian Pengembangan Kampung Kreatif Studi Kasus Kampung Kreatif Cibunut, Kelurahan Kebon Pisang, DOI: 10.34010/JWK.V5I02.216

Riyanti, A. dan Afriza, L. (2020). Kemenarikan dalam Pemberdayaan Masyarakat di Kampung Wisata Cibunut Kota Bandung. Jurnal Ekbis: Jurnalekonomi.unisla Volume 21 no 2.

Rifaldi dan Syaodih, E. (2019). Strategi Keberlanjutan Kampung Cibunut sebagai Salah Satu Destinasi Wisata di Kota Bandung. Jurnal Prosiding Perencanaan Wilayah dan Kota ISSN: 2460-6480 